conscionsness as an existent and as a knowing, and the one dwelt on previously between the orders of history and of analysis, seem to me to stand forth plainly as offering the only key to the intricacies of the present subject.

Short Summary of Results of foregoing Paper on Time-MLeasurement in its bearing on Philosophy.

There is a certain circumstance attending the initial determination of an unit of time-measurement, which marks the boundary between physical science and philosophy, both being considered as analytical modes of knowledge. The circumstance intended is, that equal times successive to one another cannot in the first instance be known as equal, unless they are taken in the concrete, as durations of motions in physical substances. This fact makes it evident, that the thoughtmachinery by which science moves begins with the assumption of physical bodies as ultimate data, whereas philosophy, which is the analysis of knowledge as such, has both these data and physical science itself among its analysanda. The same is true mutatis mutandis of the relation between philosophy and pure mathematic, which deals with the abstract relations of space, time, and number, relations which are abstracted from concrete experience, and the ascertainment of which, so far as it involves measurement, is dependent on the comparison of physical changes. Perception of the world of concrete physical objects is the first thing historically, but not analytically, in all branches of knowledge. Analytically philosophy searches farther into the elements of experience than any branch of science, not excepting pure mathematic. The philosophical distinctions (1) between bistory and analysis of knowledge, (2) between consciousness apprebended as an existent and consciousness apprehended as a knowing, together furnish the only key to the relations between philosophy and science.

\title{
JOHN OF SALISBURY.
}

\section{By Clement C. J. Webb, M.A.}

THe last time that I had the honour of reading a paper before the Aristotelian Society I took as my subject the principal work of John Scotus Erigena. I am to discuss to-night a writer who, in many respects, presents a strong contrast to the great mystic of the ninth century. We have now to do, not with a lonely metaphysician, living a life of philosophical speculation, aloof from the controversies of the 
day, and on that account exposing himself to the suspicion of heresy at the court of Rome; bat with a learned humanist of unblemished orthodoxy, for whom philosophy is a refage, always desired bat not always attainable, from the distractions of an active political and diplomatic life, and a devoted partisan of the hierarchical interest in its struggle with the civil power. So great is the difference between the two men that it seems only fitting that John of Salisbury should have been the statesman who negotiated the papal ball empowering an English king to proceed to the conquest of that Ireland, whose chief intellectual glory in the days of her independence had been Jobn the Scot.

It will be convenient to introdnce an account of John of Salisbury's philosophy by a short summary of his career. Born, at Salisbury, most probably about 1120 A.D.," he left England as a boy during the anarchic period of Stephen's reign, to study in the schools of France. $\dagger$ There he heard successively the principal teachers of the day, including the illustrious Abelard and Gilbert de la Porrée -whose work on the Six Principles, i.e., the last six categories, was reckoned, till the revival of learning, worthy of a place in the Organon of Aristotle-both of them at Paris, as well as William de Conches and Richard l'Evêque, of the renowned school which then flourished at Chartres, and of which I shall have occasion to speak again. After 12 years spent in lenrning and teaching he was present in 1148 at the Conncil of Rheims, where St. Bernard attempted to silence Gilbert, as eight years before be had silenced Abelard. Here John was introduced to the allpowerful Abbot of Clairvanx, and by him was recommended to the service of Theobald, Archbishop of Canterbury, whom he had already met at the same conncil. He soon returned to England and spent the next thirteen years of his life, down to the death of his patron, as a member of his household. This meant for him the exchange of a student's life for that of a public servant. For not only was the position of the Archbishop of Canterbury at that period always one of great political and international im. portance, but after Stephen's death in 1154 the frequent absences of his successor, Henry II, in his extensive continental dominions, left the primate, often for a long time together, the principal person in the realm. John soon became secretary to Theobald, and many of his extant letters are written in the archbishop's name. But his activity was not limited to Canterbury. He was frequently employed

* The date of his birth is often giren as A.D. 1110. Iut see Poole's Illustrations of Mediaval Thought, p. 201.

+ Metrlogicus, ii, 10.

†S. Bernardi, Ep. 361 . 
in missions to the court of Rome : ten limes, he tells as, ${ }^{*}$ he crossed the Alps on his way thither. He was the intimate friend of Nicholas Breakspear, who ascended the papal throne in 1154 as Hadrian IV (being the only Englishman that has ever flled the chair of St. Peter), and obtained from that pontiff the ball anthorising Henry to undertake the conquest of Ireland, the bull being accompanied, as John himself relates, by an emerald ring in token of the king's investiture by the pope with the lordship of the island.t But although one might have supposed that political business left him daring this period but little time for study-and indeed he is not sparing of complaints on this very point + - he availed himself of his visits to Italy to talk with persons acquainted with Greek, and probably also to promote a new translation of all the logical works of Aristotle; while in 1159 he produced his two great works, the Policraticus, or Statesman's Handbook, and the Hetalogicon, or Plea for the Study of Logic, both addressed to Henry II's favourite and chancellor, Thomas Becket, archdeacon of Canterbary. On the death of Theobald and elevation of Thomas to the metropolitan throne, Jobn continued at his post in the archiepiscopal household, and became secretary to Thomas, as he had been to his predecessor. He adopted with zeal and conviction the side of his master in the contest with Henry, thongh, as we see from his correspondence, he did not scruple to speak bis mind very freely to Thomas on the unreasonable violence and obstinacy by which the archbishop often discredited his cause. Thus in 1167 we tind him setting aside one after the other, on acconnt of the intemperance of their language, the drafts of a letter which Becket had prepared to send to a papal legate whom he believed to be adverse to his views. $\$$ Very early in the quarrel between Becket and the king, John of Salisbury either was banished or thought it safer to quit England, and accordingly, in 1163 , he crossed the channel and took refage in the dominions of the French king. Thither the archbishop followed him in the course of the next year; from that time onwards he shared all the varying fortunes of his exiled patron, and in 1170, after the hollow reconciliation with Henry, returned in his company to England, and was with him on the occasion of his murder. After that event he took part in promoting the canonization of the archbishop, which was pronounced by the pope in 1173 ; and in 1176 he became "by divine permission and the merits of St. Thomas" bishop of Chartres, a place where he had received an important part of bis early education. $\mathrm{He}$ is mentioned as present, after this date, on some occasions of historic

*Metal., iii, prol. $\quad+I b .$, iv, 42. †.g., Metal., iii, prol.

$\S E_{p p .}$.220, 232. See Robertson, Becket, p. 203. 
interest; for instance, at the third Lateran council, which confined the privilege of electing popes to the college of cardinals. He died in 1180, and was buried at Chartres. To the cathedral church of that city he bequeathed his library, a catalogue of which is extant in his will.

This brief recital of the chief events of John's life will prepare us to expect from him a philosophy such as his actually was, the philosophy of one who was not a philosopher only but also a man of affairs. Of all the classical names by which schools of thought. are designated, such an one will prefer to be called by that of Academic ; and this is in fact the title affected by John of Salisbury.* He professes a moderate scepticism which, as he puts it, "doubts of things dabitable to the wise man"; of these he gives a curions list, inclusive not only of such permanent metaphysical problems as the relations of fate and free will, the vature of the soul, and intinite progression or division, but also of physical problems such as that of the sonrces of the Nile; $t$ while he will not go to the length of those who, by denying that we have certainty on any points, reduce man below the level of the more sagacious of the brute creation.+ For this Academic position he claims the authority of Cicero, $\S$ his boundless admiration for whom is eminently characteristic of his intellectial temperament. In Cicero the cultared statesman, the interest of whose leisure lay in an intelligent survey of the various speculations of great thinkers on the world and on life, John of Salisbury recognised a kindred spirit. Like Cicero, he is an eclectic, not attached to any one system, but piclsing and choosing everywhere what pleases him best: like Cicero again he is-and here, according to the observation of Professor Schaarschmidt, $\|$ the author of an admirable monograph apon his life and works, he is unique in the middle ages-a historian of philosophy.

But John of Salisbury and his Academic position remind as not only of the Roman philosophy of the past, bat of the English philosophy of the future. It is often said in praise of English philosophy that it is not professional or professorial, bat is ciosely bound up with the rarious life of the nation, reflecting thus the traditional conception of an English nniversity education as primarily designed to train men not, for the student's desk or the teacher's chair, but for the general "service of God in Charch and State." So far as this is true of English philosophy, its leading traits are already visible in the writings of John. We have seen that,

- See Pol., vii, prol., 1-3, 9; Metal., i, prol., ii, 14, 20, ir, 7, 31.

+ Pol., vii, 2.

§ Ib., vii, 1.

|l Johannes Saresberiensis, p. 335. 
nnticipating Hume, he defends an Academical philosophy:* we may also observe in him a singular resemblance to the man whom Eugland herself has long regarded as her greatest philosopher and who certainly illustrates most conspicuously many both of the merits and defects of our national type of intellect, Francis Bacon. Again and again, in reading $J$ ohn of Salisbury, one is reminded of Bacon, and were anyone to attempt to construct from the essays of Bacon one long treatise, as some scholars tell us the Homeric epics were constracted from a multitude of independent ballads, I suspect that the result would closely resemble the Policraticus of John of Salisbury. There is indeed a side of Bacon to which John presents no parallel. All that makes Bacon more of a philosopher than of a humanist, that zeal for natural science and for his own method of discovery which leads him with deliberate intent to "discourse scornfully of the philosophy of the Grecians," is absent from the elder writer. It is of Bacon the essayist and encyclopedist, the thoughtful student of history and politics, the creator of unforgettable phrases and metaphors, that John reminds us. I think it likely that Bacon knew the Policraticus-in which, by the way, occurs something very like the famous saying that the man who is out of the right way gets farther from it the faster he runs $\nmid$-for though he does not, that I know of, mention it in any work of his that we possess, yet I am the owner of a copy which belonged to Toby Mathew, Bishop of Durbam, the father of his lifelong friend of the same name to whom he communicated the first drafts of many of his works. There are, however, more exact parallels to passages in Bacon to be found in the companion treatise Metalogicus. + This was printed in 1610, and it is not at all improbable that Bacon knew it and may have derived from it suggestions for the treatises written subsequently to that date. But in any case, whether there were indebtedness to John on Bacon's part or no, the resemblance of the two men is worth observing. Both were thorough Englishmen, and the national character revealed itself in their writings in very similar ways.

* See Hume's Essays ; Enquiry, essay zii.

+ Pol, vii, 13; cf. Bacon, Navum Organum, I, § 6. Compare also Bacon's favourite comparison of Aristotle to Antichrist as "coming in his own name," and his parallel between the spiritual ambition of the philosopher and the secular ambition of his pupil Alexander, with their anticipation in John, the contrast of Aleanander and Aristotle, whom men falsely called gods, "in that in all things they sought their own glory," with God's tme Son Jesus Christ, who everywhere sought his Father's glory, not his own. Pol., viii, 5, Bacon, de Augmentis, iii, 4.

$\ddagger$ e.g., Metal., ii, 2, cf. Bacon, N.O., I, $\$ 67$; Metal., ii, 7, cf. N.O., I, 63, de Augm., $\nabla, 2$, etc.; Metal., ii, 7, ad fin., cf. Essay on Truth; Metal., ii, 20, cf. De princ, atque orig.; Wetal., ii, 20, cf. N.O., I, § 23, §124. 
The enthusiasm for culture and philosophy which is the mist striking characteristic of John's mind had donbtless received power fal encouragement from his stadies in the school of Chartres and still earlier at Paris under Abelard.* Chartres was pre-eminently among the centres of learning in that age the school of humane letters. The educational meihods of its first eminent teacher, the Platonist, Bernard Sylvester (who had apparently retired from the active work of the school when John attended it), are vividly described to $u$ in the Metalogicus: and his successors whom John himself heard, followed, he tells us, in the same lines.t What concerns us at present under this head is the fact that Bernard, while by no means neglecting the elements of grammatical science, led his pupils to the direct stady of the great writers, discouraging the waste on anything inferior of the tire which might bave been spent on these. It is in this sense of proportion, which values the minutim of learning highly, but at the same time not as ends but as the indispensable means to the comprehension of a great literature able to impart a broad and manifold culture, that John appears as the worthy disciple of the "old man of Chartres," exundantissimus modernis temporibus fons litterarum in Gallia. The knowledge and love of classical letters which John carried with him through life will be best illustrated by the following list of Latin authors, $\ddagger$ some of whose works he undoubtedly knew in their original form-of Greek, as we shall see hereafter, he knew nothing to speak of. Among prose writers he had read in Cicero, Sallnst, Hyginas, Livy, Valerius Maximus, Seneca, Petronins, Quintilian, Frontinus, the two Plinys, Suetonius, Apuleius, Floras, Justin, Anlas Gellius, Nonins, Donatus, Eutropius, Vegetius Renatus, Servius, Macrobius, Marcianus Capella, Priscian, and the Corpus Juris : among poets, in Terence, Horace, Virgil, Ovid, Lacan, Statins, Persins, Martial, Javenal, Claadian, and Sidonius Apollinaris : and there are others who were prubably known to hira only by quotations or references in later authors. Of all these, his farourites are Cicero, Virgil, Horace (whom be calls pre-eminently $E$ thicus, the moralist) Juvenal and Persins (alike called Satyricus) and Terence "who in his Eunuchus gave us a picture of well-nigh all human life." $\$$

The wide liberty of reading which he practised, John was fally prepared to defend. All writings, he says, may be read, and the good in them extracted and used; and this is one meaning of the donation of all herbs as food to our first parents and of all flesh to the sons

- See Schaarschmidt, p. 22 ; Poole, pp. 206, 207.

+ Metal., i, 24, of. ii, 10.

$\mp$ See Scharsschmidt, ii, 3.

$\S$ Pol., viii, prol. 
of Noah, that is, to man in a state of innocence and to man restored by grace after punishment.* Thrice does he avail himself of the ambignity of the word scripturce to quote from St. Jerome the phrase, "Love the knowledge of Scriptures and thou shalt not love the sins of the Elesh," in reference to the elevating influence of literary stadies in general. $\dagger$ But this humanism of our author was tempered by a really critical spirit. Thas, while Bernard of Chartres, like many humanists in the l6th century, delighted to attempt a reconciliation of the two great masters of ancient thought, Plato and Aristotle, John, after recording an instance of this syncretistic interpretation, adds, "bat I think they [Bernard and his followers] are too late and have vainly laboured to reconcile those when dead, who, as long as they lived and might have been reconciled, were of different opinions." + And just as bis critical spirit keeps his humanism within bounds, so does his literary taste save him in the character of philosopher from losing himself in the arid maze of the merely technical discussions wherein many students of his day occupied themselves. He has no mercy for the mere grammarnongers, or logic-choppers, who spend their life in verbal quibblings which are, at the best, useful only as schoolboy exercises.§ He complains of those who read all literature as he himself adinits it is right to read the inspired books, that is, with an anxions attention to every jot or tittle, instead of understanding each sentence in the light of the context and general drift.\| He is especially severe on those whose logical studies begin and end with the Isagoge of Porphyry, forgetting the merely introdactory character of that book which its very title proclaims. $\mathrm{I}$ He perceived the preposterousness of raising the deepest philosophical questions on occasion of the passing observations of this elementary treatise, instead of waiting for the guidance of Aristotle's fuller treatment of them in the more advanced works of the Organon. "They read," he says, "the end in the title," regardless of the true order of instruction; they find in Porphyry ererything-Topics, Analytics and Elenchi.** The criticism was by no means unneeded. Hauréan has observed that the great question of aniversals was first raised for the mediæval mind by a sentence of Porphyry's Isagoge. We may add that the earliest scholastic work in regular form which remains to us, the De Rationali et Ratione uti of Gerbert, afterwards Pope Sylvester II, is a discussion of what is at bottom a really deep problem of philosophical logic in the form of a commentary on another phruse in the same book. But for

- Pol., vii, 10.

$\$$ Metal., ii, 17.

T Metal., ii, 16, iii, 1.
† Pol., vii, 10; Metal., i, 24, Ep. 143.

$\S$ Pol., vii, 12.

* Ib., ii, 19. 
John of Salisbury, Porphyry's work is a mere preface. To linger over him is to refuse to put away childish things for the mature stadies which beft intellectral manhood. The incidental expressions of Porphyry are often not strictly correct; thus, in speaking of the genus of man and of animal, he makes more of the body than of the soul; but being used only as illustrations they do well enough for the purpose in hand. One should read on: anthors and books often interpret one another."

There is a humorons description in the autobiographical chapter of the Metalogicus, of his return after ten years' absence spent chiefly in literary and theological studies to his first school on Mount St. Geneviève, by Paris, where he had heard Abelard, Alberic, and Robert, of Melun, in logic. "So it seemed pleasant to me to revisit my old comrades whom I had left and whom the study of Dialectic still kept upon the Mount, to confer with them on our old difficulties that we might, by comparing notes, test the progress we had respectively made. I found them the same as they had been and in the same place, they seemed neither to have succeeded in solving the old questions, nor to have added one smallest jot thereto. The same aims as had inspired them before inspired them still. In one thing alone had they gone forward, they had unlearned moderation, they knew not modesty; so that, indeed, one might well despair of their amendment. Thus I learned what may easily be inferred, that as Dialectic is an aid to other sciences, so if it be left alone it lies bloodless and barren, nor doth it quicken the womb of the soul to bear the true frait of philosophy, unless the soul conceive from another." $\dagger$ Here we may note a remarkable anticipation of Baconian language on the sterility of merely abstract studies, although the application is no donbt different. What John insists apon is not that logic-" dialectic" as he generally calls it-is useless, but that it is so when isolated from other sciences, to which it should be a means and a suide. He is careful to explain that his contempt for mere logic is not a contempt for logic itself. His Metalogicus is a plea for the thorough study of logic in answer to a bitter opponent of his own, whose personality, out of charity and kindness for an old acquaintance, he veils under the name of Cornificius-an obscure rival of Virgil's, mentioned in Donatus' life of that poet-who with his party would seem to have occupied in the intellectral world of the time a position not unlike that attributed by Plato to certain of the sophists. $\ddagger$ Cornificianism, as described by John, combined real ignorance with great pretentiousness, and despised accurate study of the elements, vet never proceeded to a real grasp of that for which
* Metal., iii, 1.
$+I k$., ii, 10.
$\pm I b$. i. 
such study is the ouly preparation. The school from which Cornificius proceeded had busied itself with the most trilling questions, and this was called neglecting the letter to find the spirit: in the statement that Hylas was from Hercules it found the inner meaning that a valid argument comes from a bold and powerfal metnod of arguing; it discussed whether a pig going to market was driven by a man or by a rope, or whether one bought a hood when one bought a whole cloak.* By a natural reaction from such follies, the Cornificians assailed all logical, grammatical, and rhetorical education as superfluous. If a man has a natural gift for eloquence, rhetorical teaching is superfluous; if he has none, it is useless. $\dagger$ This attack is really, as John points out, an attack on all learning and all philosophy. Everything is left to nature ; art is cried down.+

Bat John prefers to regard intellect as that which "proceeds from nature, is added to by practice, is restrained by overmuch toil, is sharpened by moderate exercise." The mental temperament best suited to philosophical training is neither the impatient and higbflying "advolans," nor the unambitious grovelling "infimum," but the "mediocre"; and here again we seem to hear a spiritual kinsman of the father of inductive philosophy. $\S$ The true scholar must slowly and painfully ascend through trivium and quadrivium to the higher problems of physics and of ethics.|l He must be a dialectician, but must remember that the universal range of dialectic does not make it superior, but auxiliary, to the other sciences. From them it derives its subject-matter, in the form of quastiones or problems : and then in its turn it directs as in the discussion of these, and supplies a collective method applicable in all departments of knowledge where we seek probability, though every science has its own proper constitutive method as well. T John is not ignorant of Aristotle's distinction of "apodeictic" or demonstrative logic from dialectic, but holds that the realm of necessary trath is beyond his range. Demonstration, he observes, belongs chiefly to the science of geometry, which is little studied except in Spain and Africa, where, as also in Egypt and among some of the Arabians, it is practised still in connection with astronomical investigations. At any rute, no one should aspire to this higher demonstrative science who has not made himself master of dialectic or probuble science."*

In everything John takes the same high and generous view of intellectual culture. He has ungrudging admiration for all the really distinguished teachers of his day.tt His acquaintance with and obligations to the great heresy hunter and enemy of free thought,

$\begin{array}{llll}\text { Metal., i, 3. } & +I b ., \mathrm{i}, 6 . & \ddagger I b ., \mathrm{i}, 10 . & \S I b ., \mathrm{i}, 11 . \\ \| I b ., \mathrm{i}, 12 . & \quad I b ., \mathrm{ii}, 12,13 . & * \text { Ib., ir, } 6 . & \dagger+\text { See Metal., i, } 5 .\end{array}$


Bernard of Clairvaux, do not hinder him from paying all due respect to Abelard and to Gilbert. His enthusiasm for the ancients does not betray him into any pedantic and unreasonable neglect of his contemporaries. He treely nsed, he says, in his controversies the works of men be knew, not despising modern books because they are modern, but using them "the more familiarly that I knew them more certainly to be the gifts of faithful friends." It seems to him a foolish and ungrateful thing to accept an opinion on the anthority of Coriscus or Brisso or Melissus, mere exauples in Aristotle (though, of course, this is true only of the first-named) and otherwise nnknown, and reject it becanse it comes from Gilbert or Abelard or Adam"that is, probably, Adam da Petit Pont, an eminent Aristotelian whom John knew in Paris, afterwards Bishop of St. Asaph in Wales. None of his contemporaries, be thinks, bas advanced opinions so absurd as some of the ancient philosophers have done. And one should gladly confess one's indebtedness to others : those who object thereto should remember that they may come themselves to be quoted in like manner as good authors, when contemporary jealousy has passed away. $\dagger$ He notes improvements and additions in logic due to modern writers, as, for instance, Abelard's in the doctrine of modals and hypotheticals. ${ }_{+}^{+}$He quotes a remark he had heard Abelard make, that a man might now compose a book nowise inferior to Aristotle's in truth or elegance (this is said à propos of the De Interpretatione), yet it would not have the same anthority. We reap what our fathers have sown: we do easily what they found out how to do with mach time and pains : our age knows more than theirs, not by its own exertions but through the labours of those who have gone before. Bernard of Chartres, he tells us, compared us moderns to dwarfs, standing on the shoulders of giants and seeing more and more distant things than they to whose great stature we owe our exalted positiou. So no one is contented with Aristotle's De Interpretatione, bat all add to it from various sources. This is made the more necessary by changes in the meaning of technical words, which are inevitable and which we must not fail to take into account. "Usage is mightier thian Aristotle" in altering and abolishing words, bat human will cannot affect the trath of things. Let as keep old words if possible; if not we must keep the meaning and let the words go. Who could treat the "battle of the books" or the "interpretation of thought in words" more judiciously than John does here? §

This large-mindedness, indeed, may be fairly said to be not unconnected with his defect as a specnlative thinker. The imperious craving for consistency which makes a man either a heretic or the

* Mretal., iii, prol. $\quad+I b . \quad \quad \ddagger I b .$, iii, $6 . \quad \S I b .$, iii, 4.


nncompromising foe of all that may make for heresy, was alien to his mind. Philosophy interested him mainly as an instrument of calture. He would learn from every man and from every book whatever they might have to teach him, content to accept whatever accorded with, reject whaterer disagreed with, the religious creed which he held with whole-hearted derotion to be the highest trath attainable by men. That is the principle of his criticism of ancient philosophies in his poem called Entheticus de dogmatibus philosophoerum. From such a man we shall not look for original specalation, but rather for that intelligent and sympatbetic account of other men's views which, as a matter of fact, constitutes perhaps the main interest to us of his philosophical writings. Thus he gives us a most valuable chapter in the Metalogicus on the different opinions entertained by the various schools of his day on the great question of Universals, a question which is always, in one form or another, one of the principal problems of philosophy, and which at that time, when thought was dominated by logic-no remains of Greek philosophic literature being extant (the Timous of Plato in the translation of Chalcidius alone excepted), which dealt with any other subject-presented itself as a logical question. John enumerates nine views on this topic-three nominalist, six more or less realist." For himself he holds to what he conceives to be the teaching of Aristotle, "genera et species non esse sed intelligi tantum." This is not, however, mere ordinary conceptualism: for, he thinks, to ask "what universals are" is a vicious way of putting the question, since they are not in the category of substance at all, but rather in that of quality. Thus he will not say they "are" voces or sermones or " intellectus," but merely that they "are conceived." They do not exist except in the particulars : apart from these they are but phantoms of our minds, the relics of the real similarity or " conformities" of things left in the mirror of the soul. But they are not thoughts of nothing: the understanding in taking them for objects is not cassus : the abstraction by which they are constitated is fidelis et quasi quadam officina omnium artium. Things have only one way of being; of being understood or interpreted many ways. Their manifold similarities are the archetypes of our conceptions of genera and species into which they are grouped; and accordingly God is described in Scripture as making things " after their kind," but never as making universals over and above particulars. The mind for convenience' sake introduces universals as a compendious way of stating a number of facts : it then reflects its own "agitation" back into the world : regarding one thing as e.g., Plato, man, animal, which 
is in actual fact one only thing, of which the mind seems to make three, becanse its own investigation of the nature of the thing has three stages. Such appears to me to be $n$ tolerably adequate representation of John's views on the question of his day. He does not omit to add, after his manner, that we may nse the substantive rerb loosely of universals without blame, so we do not make out of our usage a theory of their independent existenco; nor to put in a proviso that if be here takes a line with Aristotle against Plato, despite the greatness of the latter philosopher and the sapport given him hy St. Ancrustine, it is in matters of peripntetic or dialectic- (for in the l2th century peripateticus and dialecticus were used as synonyms: Abelard is regularly called Peripateticus Palatinus)-where it is per. missible to follow the head of the peripatetic school, whose doctrine moreover fits in best with the conclusions of logical science and occupies the vin medir between Platonism and nominalism.

The true bope for the progress of logical science seemed to John -and here he was no doubt right-to lie in the further study of Aristotle. Accordingly he is the first western writer of the Middle Ages who shows knowledge of the whole Organon, a new translation of which he probably had some part in cansing to be rade. Abelard had only the Categories and De Interpretatione in the translation of Bcethius: of the other works only the names were known to him. John of Salisbury gives us a complete abstract of the Categories, De Interpretatione, Topics, Analytics, and Sophistici Elenchi in turn. The Categories he calls the elementurius, the De Interpretatione the syllabicus, the Topics the dictionalis." He observes, by the way, that the predicables and the question of genera and species are far better treated in Top. $\mathrm{i}$ and iv respectively than in the Isagoge of Porpbyry. + The Topics, as dealing with the sphere of probability, appear to him a specially useful work. Yet Categories, De Interpretatione, and Topics alike are all only introductory to the Analytics.t Here he complains much of the difficulty of the language; in spite of which, however, the books are the best account of their subject. He notes the incompleteness of Aristotle's doctrine of modals, which required supplementing by Theophrastus and Eademus, || and agnin the disappointing natare of the chapter on physiognomy with which the Prior Anulytics end. Nowhere had John ever met a man to whom it had given perfection in the knowledge of nataral dispositions as it seemed to promise. $\|_{\text {But }}$ if the Prior Analytics are difficult, still more so are the Posterior.** This is partly due to the sulject, which is demonstrative science, now little practised, aithough it was by his
* Metal., iii, 4, 6, 10.
$+I b$., iii, 5,7 .
$\S I t ., \mathrm{iv}, 2$.
if $I b$., it, 4.
TIb, iv, 5 .
$\pm I b$., iii, 10.
**Ib., ir, 6. 
eminence in this that Aristotle earned the title of Plilosopher par excellence.* The perplexity which John candidly confesses he feels in making out the meaning of these treatises is evidenced also by the fact that in his account of them he keeps less closely to his text and ekes out his author by the belp of other writers, Plato, Cicero, Seneca, Cassiodoras, Hugh of St. Victor.t He remarks on the oraission of any treatment of hypothetical reasoning, but observes that the germ of this part of logic is to be found where Boethius found it, in the Aristotelian doctrine of modals. He hazards the suggestion that Aristotle's omission of this subject was not unintentional; for the work of those logicians who had here supplied an account of it seems, says John, more diffcult than useful: and moreover, had Aristotle written of it in his own style, it would most likely have been so hard that no one but the Sibyl could possibly have understood it. $\ddagger$ The book on Sophistic Elenchi, which is epitomised last, is praised as useful to young men in making them less liable to be tripped up in argument. $\S$

But Logic was not the only province of Philosophy with which John deals, nor is it that on which he left his deepest mark. Metaphysic and physic indeed he caunot be said to touch. He sees how great a preparation must be made before such subjects can be titly approached: and as yet the works of Aristotle dealing with these sciences were not available for the guidance of the intellect of Western Europe in its tirst essay to tread their paths. Interest in political philosophy, however, distinguished the 12th century, and in political philosophy John holds strong and independent views. They are expanded in the Policruticus, where they take the form of a comsmeutary on a treatise ascribed by John to Plutarch, which was called the Institutio Irajari, and professed to have been written for the instruction of that emperor. This treatise contained an elaborate comparison of the body politic to the body natural. The priesthood is the soul, the prince the head, the senate the heart, the judges and governors of provinces the eyes, ears, and tongue, the ofticers and soldiers the hands, the courtiers the sides, the quastors and registrars the digestive orguns, the husbandmen the feet.\|

This arrangement gives occasion to many interesting observations on the several classes enumerated, but what we are chiefly concerned with is his doctrine of the priesthood and of the priuce. In his account of the latter the teaching of psendo-Platarch is supplemented by that of Deuteronomy. The true priuce is oue in whom no individual or selfish passion interferes with his perfect embodiment of
* Metal., iv, 7 .
+ Ib., ir, 10-16.
$\ddagger I b .$, iv, 21 .
\ $T b ., \mathrm{iv}, 22$.
\|I Pol., , , 1, z. 
the law of justice; his will is aniversal, he represents that disinterestedness which is the very principle of goodness.* Bat if he allows himself to fall from this ideal, the ruler is no longer a prince bat a tyrant, the image of the devil as the prince is the image of God. $\dagger$ Such a one, according to John, it is lawful, nay right, to slay. $\ddagger$ This extreme position, afterwards I believe not uncommon in the mediæval schools, but first annonnced by John, is closely connected with his high churchmanship. The struggle of Pope Gregory VII with the Emperor Henry IV in the 1lth century had its parallel on the local stage of English politics in the shortly subsequent contest of Anseim with the Red King and his brother Henry I. The same quarrel was fought out in the next century between Alexander III and Frederick Barbarossa, between Thomas Becket and Henry II. In this case the great power and wealth of an English king, who was also ruler of Normandy, Anjou, and Aquitaine, made this dispute with the primate of Canterbury scarcely second in general importance to that which the pope was waging with the emperur and an anti-pope recognised by the emperor alone among the great princes of Christendom. John of Salisbury, as we have seen, espoused the cause of the hierarchy. This did not prevent him from uncompromising censure of the church as it was. None could speak more severely than he does of the venality of the papal court, of the reckless ambition of prelates, of the corruption of the monastic orders. Where no one questions the authority of an institution, such criticism of those who actually represent it has not the bearing which it would have where the institution's claims, not in detail but in essence, are matters of dispute, as happened with the Catholic church at the period of the Reformation. In "ages of faith" the stoutest churchmen can be, and naturally are, the londest in denouncing evils which bring discreait and weakness on the church. John thus performed an obvious daty in his plain speaking about ecclesiastical abuses, but his language makes him an important witness against the fanciful idealization of the mediæval charch which was once the fashion in certain circles amongst us.

It was natural for a man of John's temperament to be of the ecclesiastical party, since it was natural for humanism to ally itself with the catholic ideals of the Latin church rather than with those which were merely national. Not that John was unpatriotic. His patriotism-which it is worth while to observe is English patriotism, showing no feeling of the distinctness of the Saxon and Norman elements in the nation-often finds vigorous expression in his writiugs.§ It sometimes assumes, as patriotism is apt to assume,

* Pol., ir. 2, 5 ; viij, 17.

$\pm I b$., viii, 20 .
$+I b .$, riii, 17.

$\S$ Freeman, Contemp. Rev. 
quaint forms : as when adding to his list of tyrants who have come to violent ends the name of Severus, the founder, as he believes, of his own hirthplace, Salisbury, he remarks that that emperor's death at York was not due to poison, for Britain ever abhorred poisoning and knows not how to tight against its princes, but rather bow to draw for them unconquered swords; so that his punishment for persecuting the Christians must have been reserved till after his death.* Agaiu, he contrasts the state of the English military power in his day after the decay of discipline under Stephen, unable to check the Welsh raids upon the marches, with the ancient glory of the British arms in the days when Brennus proceeded from our island to the sack of Rome, and required to repulse him no mortal man but the god of Delphi.t Yet in expounding his theory of civil government, feudalism simply disappears from his sight: the institations of the universal Roman empire fill his mind to the exclusion of those which already existed in his own country. Of the civil law he speaks with characteristic reverence; the act of Stephen in confiscating the copies of the Roman code belonging to Archbishop Theobald and others, and in silencing the lectures of Vacarius thereapon is classed with the impieties of Uzziah and Antiochus Epiphanes in Jewish history.+ In his duable character as the man of universal learning and the travelled man of affairs, as the student and the diplomatist, he looks for a remedy of the confusions and barbarisms of his time to a state in which the priest, the representative of the spiritual and moral order will be above the secular authority, and keeping it in check will prevent it from degenerating into the selfish violence of cyranoy; for a remedy of the rain, logical, and grammatical quibbling, and the even vainer affectation of superiority to logic and grammar which he sees around him, to a general culture, in which sound grammar and sound logic will bear ap a stately structure of science, of which theology will be the roof and crown.

The way to the realization of this latter ideal lies for him through the thorough assimilation of the ancient culture contained in the literatnre of Greece and Rome. Thus we see well represented in him that aspect of the intellect of his period in which it seems sworn, like its own knights of Arthur's table, to a quest, the quest of the Greek literature which, like the holy granl, bad vanished from the world which it hald once glorified by its presence. The occasional glimpses of it vouchsafed to certain fortunate scholars, like the rare visions of the mysterious cup, did but avail to make keener the longing after its possession. It is but one sign of this that so many of the most celebrated works of the time bore Greek titles, or what were meant

* Pol., viii, 19.

$+I 6 .$, vi, 16, 17.

$\pm I b$, viii, 21 . 
for such. Thus we have St. Anselm's Monologion and Proslogion, Bernard of Chartres' Megacosmus and Microcusmas, William of Conches' Dragmaticon (i.e., Dramatican), Abelard's Hexaemeron and the Phrenophysicus of anknown authorship mentioned by John of Salisbury as the best summary of the philosophical theories on the Soul. So our author bas his Policraticus, his Metalogicus, his Entheticus. None of these three words are really Greek, but all of them are meant to be; the first is probably meant for the States. man's, or more literally, the Suate-ruler's book; the second, he tells us bimself, means a plea for Logic; the last is the name of his poems in elegiac metre, one an introduction to the Policraticus, while the other, "Entheticus de dogmatibus philosophoerum," forming an epilogue to one or both of his larger works, and addressed (like the smaller Entheticus) to his book personified, contains a sketch of the history of philosophy, and a political invective in which the real names of the persons assailed are exchanged for others borrowed from the late pseudo-Plantine comedy Querolus, and other ancient sources. It has been supposed, with great probability, that John intended this name Entheticus or Eutheticus, of which, as it stands, nothing can be made, for Nutheticus, the Counsellor. His position as a seeker after the lost Greek culture is marked again by his interest in the new translation of Aristotle, and the eagerness with which he seems to have availed himself of the chances which presented themselves, during his Italian travels, of conversing with persons who knew Greek; just as a hundred years after his time Roger Bacon is found crying out once more for new and better translations of Aristotle, and censuring, with his accastomed strength of language, those wbich were current in his day. It is true that on one occasion John says that he will match his Latin Cicero with any Greek philosopher,* but this is simply a piece of the patriotic tradition of the Latins, aided by John's personal sympathy with Cicero. John is a humanist, as were the men of the renascence: but the mediæval humanist died without having received the promises which were fulflled to his successors, through the revelation of Greek literature to Western Christendom in the 15 th and 16 th centaries.

I have tried to set before you not a detailed account of John's writings, which do not present as with a complete philosophical system capable of being criticised or discussed, but rather the picture of a man "the central figure of English learning" in his time, an excellent example of the political earnestness, the unpedantic culture, the sound common sense, which Englishmen love to regard as characteristic of their nation. Of John as a politician and scholar 
we have spoken. His common sense, sufficiently apparent in his philosophical views, is also illustrated by his uncompromising attack on judicial astrology, and on magical pretensions in general, in the first and secoud books of the Policraticus. He has no faith in the objective truth of the stories of witcheraft which obtained credence in such high quarters as late as the 17th century. The Witches' Subbaths, whicl some supposed witches assert that they have attended, are only dreams sent by evil spirits." T'be one incident which John telis us of his boyhood in England is highly characteristic of his unsuperstitious temper. A certain priest, to whom be was sent to learu his Psalter, indulged in the not even now extinct practice of consulting the "magic crystal" by means of an innocent child. He attempted to use John, among others, for this purpose. "It happened that he made me, and a boy somewhat bigger than I, after some wicked preliminaries, to sit at his feet and attend to the sacrilegious business of this mirror, so that by our means there night be shown him that which ho sought, either in nails smeared by some consecrated oil or chrism, or in the clean smooth body of a basin. When, then, after first nttering some names which seemed to me, by the horror I felt at them, child as I was, to be those of demons, and also making some preliminary adjurations which, think God, I do not know, my comrade had declared that he saw some shapes, dim and cloudy incleed, I for my part turned out so blind at this business, that notbing appeared to me but the nails or basin and the rest of the things that I knew to be there before. So I was after this judged useless for this sort of practice, and was condemned, as a hinderer of these sacrilegious proceedings, not to approach to any such, and, as often as they had resolved to make these practices, I was shut out as an impediment to any divination. So gracious was the Lord to me in my tender age."* With this quotation, so illustrative of the rational piety and judicions scepticism of our author, we may for the present take our leave of him.

THE PHILOSOPHY OF MR. SHADWORTH HODGSON. By G. F. STout, M.A.

"Tue Principle," says Mr. Hodgson, "which I think I have established beyond the possibility of reversal is that of Reflection. Whatever other parts of the system may be found to be untenable this

$$
\text { * Pol., ii, } 17 . \quad \quad+I b ., \text { ii, } 28 .
$$

